\title{
Nation and State
}

\section{Abdullahi Abdulfatai Akanmu}

Political Science Department, Ibrahim Badamasi Babagida University, Lapai Niger State Email: abdulfataiolokogboro1996@gmail.com

\begin{abstract}
:
This paper examines the nation and state with their features, merits, and demerits. The level of Nigeria as a nation-state is being appraised from the early of 1914 to 1963 and furthermore, examines the brief history of Nigerian politics from pre-1900-2020. The data collection is base on secondary data from the reliable sources such as textbooks, University lecture's books and some other online sources. Therefore, this paper will promote high level of understanding among the students in the primary, secondary schools, higher institutions, and those in national-governmental positions in the various offices in order to differentiate between the level of nation and state, and how is it being measured in various sovereign states across the globe.
\end{abstract}

\section{Keywords:}

State; Nation; Nigerian politics; Nigeria as a Nation-state

\section{Introduction}

State and nation are different concepts which pivotal to the student of politics. Nation can be defined as a group of people who are having common race such as religion, languages and some other social relations. While the concept of state is a high governmental organization in which power and authority are being carried-out among the governmental and non-governmental agencies in a given territory. Therefore, whenever, state and nation come together with their attribute, will now regard as nation-state which is governed with strong sovereignty and multiethnic groups in a given society. For instance, Nigeria, USA, India, China, Ghana, etc are good example of nation-state because all the countries have the attribute of state and nation in a different conceptualization. Indeed, all the independent countries across the universe are regarded as nation-state because they have been governing with their external and internal sovereignty.

The historical background of Nigeria could be traced-back to pre-colonial epoch in pre-1900 when the traditional rulers ruled their domain before those powers and authorities later declined in 1976 as result of local government reform. Before the reformation of local government, the colonial masters were being colonized their economic and socio-political institutions right from 19th to the middle of 20th century. Southern and Northern protectorates were amalgamated by Sir. Fredric Lugard (the first governor general from 1914 to 1919). Aftermath, the Sir Clifford was taken over in the 1922-1946 and firstly adopted first political party to be formed as Nigerian National Democratic Party (NNDP) which led by Late; Hertmaculay. This was how Nigeria was governed by various colonial masters to the end of 1959. Therefore, since Nigeria had been given independent from those colonial masters have not have true democracy despite the fact almost 15th head of states and governments in both civilian and non-civilian government. 


\section{Methodology}

This paper adopts secondary sources of data in order to look at nature of nation and state and some other political history in Nigeria. Such data are: news-paper, textbooks and other online sources with independent lectures' notes.

\section{Discussion}

\subsection{State as a Concept}

State is one of basic terminology in political science. State can be seen as room and pallor which governmental decisions are taken place. Room and pallor will be referred to general government and regional government who making certain decision for the citizens. The modern term of "state" is originated from the world "Status" and was firstly used by Niccolo Machiavelli (1469-1527) in his work titled as "the Prince".

State can be defined in deferent perspectives as some scholars have coined. A state is high social organization which every individuation occupies for social development. Social organization is a group of people who come together to submit their natural liberty for a particular community to carry out either absolutism or representative government with democratic establishing or authoritarian forming. In this manner, state can be formed in form of two perspective either by coercive or decoercive structure.

State may be sees as a group of people who occupies a particular community with some governmental institutions, in absent of foreign domination. Government institution can be referred to bureaucratic civil service, public service, government organization (executive, judiciary, and legislature), among social institution like religion, education, etc. Any particular places being occupied by these institutions are referred to territory and must also have both external and internal power.

There some philosophers related to the contribution of state starting from ancient to modern period. According Aristotle sees state as family basis which later metamorphoses to village and from that village transform to state. Therefore, there are three stages of state based on Aristotle view as aforementioned as Family to Village to state. family is related by blood who come together in order to have public benefit makes them to form village, and Villages is a group of families who come together for social, political and economic structure in a micro level, this is later transformed to State. A state according to this great man is a group of villages who come together to have macro government without external and internal domination. However, some scholars like Plato looks state inform of three souls. According to him state constitutes philosopher kings, shoulders, and producers (i.e wisdom, sprite and appetite), all these made up state. Nevertheless, Thomas, Lackey and Rousseau see state as social contract theories which allow individuals to donate their nature right either by absolutism or check and balance among the state. Therefore, state is a basic concept that allows social value, social institution to form.

According to Woodrow Wilson, "State is a people organized for law with a definite territory. Sedgwick sees State "as combination or association of persons in form of government and governed and united together into a political organized people of a definite territory". 
Element of state:

The element of state can be classified into two structures;

1. Physical structure of state

2. Political structure of state

\begin{tabular}{|l|l|}
\hline The Physical Structure Of State & Political Structure Of State \\
\hline Definite Territory & Government \\
\hline Population & Sovereignty \\
\hline
\end{tabular}

The physical structure of state: are the basic structures of state that firstly constitute state before any others which are:

a. Definite Territory: is a place where a group of people occupied as geographical location which constitutes Land, Forest, rivers and sky. All these are vital concept used to defined territory that is reason why some countries are separated with river, land, and forest for the social peace. The territory can be also referred to a boundary that constitutes either homogeneous or heterogeneous ethics therefore; defined territories are the background creation of a state which is indispensable conception among attributes of state.

b. Population: population is a group of high living things that occupies a particular territory. The livings things are referred to human being or peoples that exit in the state. During the census, the government officers do require to count the human that are existing in a particular state, therefore population of people are the organizers of state. For examples: Nigeria population census in the 2006 has 133,647,354 people, India has a population of $102,70,15,247$ people according to 2001 census etc.

Political structure of state: this is another concept necessary for the creation of state which stands as political arrangement of state. There are two forms of political structure of state:

1. Government: is an institution of state which is making, adjudicating and implementing the law to a particular citizen to obey. the real information of state must have the real attributes of government which refers to arms of government either in central, sub national and local government.

2. Sovereignty: is supremacy of law that binds each and everyone without war and domination either from external or internal. Before a state can be form as a state must have both internal and external sovereignty that regulate the conduct of individual in a society. However, a state without this could not be regarded as state. Therefore sovereignty is a pivotal concept necessary in the state creation.

\subsection{Merit of State}

1. Basic amenities: it is responsible of state to provide some basic amenities for the benefit of individuals living that geographical location.

2. Promote social institutions: the social institutions are very important in the state. State promotes socio-religious group, education, culture and governmental agencies.

3. Social contract: the sate allows social relation of two or more people to come together with civil government

4. Right of individual: it is duty of state to promote the right of individual in a society.

5. Government structure: the government structure is basic necessary of state that gives all government agencies to exercising their governing power either directly or indirectly.

\subsection{Demerit of State}

1. Terminating of less privilege to rule: in authoritarian and democratic state does not promote equality among the citizen. 
2. Sharing of allocation: is one of problems of state because it is responsible of state to make sure that federal cakes must be sharing all across the state equally without egoism and sentimental with favourism.

3. state is normally lacked economic finance in order to promote social amenities

4. Conflict making: the conflict making is great problem among the individual in the state because if the government refuses to do some certain duties it will lead to conflict among the state.

5. Social class: one of the problems of state is also contributed to social division among the citizens where someone will have means of production and other will be poor. As we know that everybody must be equal in a state.

\subsection{Nation as Concept}

The nation was originated from Latin word "notion" which means birth or race. However, some perspectives the term nation and state are normally used interchangeably. According to Leacock, a nation is a body of people united by common descent and language. Nation can be defined as a group of people who have common language, race, tribe, food, and social value lived in a particular society. The relation of state and nation are the only common race, religion and some other make the different. Because state does not promote common culture which are very important in any community. Without social believe there won't be state. For instance, Nigeria has over 250 ethnics who spoke different languages such Yoruba is a nation, Hausa/Fulani are Nations, Igbo is a nation, Tiv is a nation among other tribes, are having different races. Therefore, any communities have the same language, mode of dressing, food, religion, mode of dancing are referred to nation. In India has over 1000 ethnics who have different cultural believes and also applicable to china which has different cultures and some other countries.

Types of Nation

The nation can be categorized into three forms base on language and mode of dressing namely:

1. General Nation

1. Sub-general Nation

2. Semi-nation

\begin{tabular}{|l|l|l|}
\hline \multicolumn{2}{|c|}{ Three Classification Nation Base Of Language And Mode Of Dressing } \\
\hline $\begin{array}{l}\text { Outer cycle nation } \\
\text { (By one) }\end{array}$ & $\begin{array}{l}\text { Inner most nation } \\
\text { (By few) }\end{array}$ & $\begin{array}{l}\text { Inner one nation } \\
\text { (By many) }\end{array}$ \\
\hline General nation & Sub-general nation & Semi-general nation \\
\hline
\end{tabular}

The general nations: are nations which recognize in international arena as result of high numbers of peoples spoken language and emulating their mode of dressing. There are some national languages that being recognized in global arena therefore, such culture can be referred to general nations. For instance, the English, French, Hausa, and Arab spoken are highest recognize language in international arena because it is hard to go to any countries all over the world not see anybody speaking all the languages.

Sub-national nation: this direct opposite to General nations. This type is very common all over the countries because two or more societies have their domestic language which stands as their ways of communication in across their community. For example Chinese' language is most spoke language in all across the world due to their population and Hausa/Fulani, Yoruba and Igbo have highest people spoke the language in Nigeria. Therefore, every region all across the world has their dominant languages and cultures valued most. 
Semi-nation: these are minor languages that occupy a particular country. For instance out of 250 languages in Nigeria just only three languages regarded as national language others are semi-national cultures and that is how applicable to other countries.

Merit of nation

1. Common culture: every nations must have the same language, mode dressing, food, house structure and dancing that promote their cultural value

2. Homogenous political believe: in any homogenous society must have the same political system that will promote their society for some social amenities.

3. Unity and diversity: every nation must have unity and diversity because there won't be tribalism among them due to common language. As result will make them to love one another.

4. Homogenous economic structure: nations are having the same domestic economy which will stand as their mode of production in order to develop their community or society.

5. Common religion: all these nations do have the same religions which will stand as their faith to their God.

Demerit of nation

1. It promotes social conflict within the ethnic

2. It also promotes favourism, egoism, and sentimental

3. There is backwardness of traditional socio-economy and political believe

4. It also lacks internal and external sovereignty.

\subsection{Nation-State}

This is combination of nation's attributes and state's attributes which stand as social development. Nation-state is group of people with multiethnic or mono-ethnic in a geographical location which have internal and external control and governmental institutions. For a country to become a nation-state must have all the ingredients of state like: Definite territory, Sovereignty, population and government, and join with all the silent features of nation known as: common languages, religion, mode of dressing, food, political structure and economic believe that will serve as development of any particular societies. There are various examples of nation-state: Nigeria, USA, China, UK, Ghana, India, etc.

Feature of nation-state

1. Geographical location

2. Social cultures and religions

3. Political and economic independence

4. Standard governmental institutions

Merit of Nation-state

- It promotes domestic domination

- There must be strong economic and political structure

- It promotes cultural diversity

- It also promote social amenities

- It gives other social institutions to function such education, religion, etc.

Demerit of Nation-state

- It promotes internal and external conflict among the two or more ethnics in society.

- It does gives room to equal sharing either politically and economically 


\subsection{Nigeria as A Nation-State}

The historical background of Nigerian as Nation-state began during the amalgamation of Northern protectorate and Lagos-southern protectorate which was centered on the administration of late sir Fredric Lugard in 1914. During this period, he formed this amalgamation in order to unite all the ethnics in two protectorates for their political and economic improvement. However, many Nigerian scholars have argued that Nigeria did not fully adopt Nation-state due to some concrete evidences. According to them, they realized that in that of 1914 where happened to be amalgamation of two protectorates to form protectorate of Nigeria was lacked political and economic sovereignty. According to the world views believe that nation-state must have sovereignty which stands as internal and external power but during this period economic and political sectors were being dominated by former colonialists from 1914-1960. Event in 1960 where Nigeria declared for independent, nationstate as a concept still lacked sovereignty because some area of sub-national responsibilities were still given to formal colonial masters to hold such President, area of courts etc. therefore it was only 1963, Nigeria could be realized as nation-state due to Queen Elizabeth left Nigeria and power of judicial council returned to supreme court. According to some dependent theorists like: Emmanuel, Amin, Frank, etc believe that it was only political independent gave to third world countries and lack economic independence.

\subsection{Brief History of Nigerian Politics from Pre-1900 - 2019}

Nigeria is a democratic country which allows Multi parties system by constitution rather than constitutionalism and however, it's de-facto two parties system. The constitutional power or power breaking is being shared between three tiers of government in a whereby central government has exclusive legislative list, both states and central government have concurrent legislative and Local government has residual list which promote proper federal status as its stated by the constitution of 1999 as amended.

The historical background of Nigeria has directed the notion of democracy to the era of pre-colonial administration in Eastern part of Nigeria and lack of democracy in western and Northern part of Nigeria as result of centralized monarch system. The decentralized system of government in Eastern part allowed individuals such as age-grade, council of elders etc to participate in their political system without dictatorship? But kindly different to the western and Northern parts of the country for instance in the arena of western part of Nigeria did not allow individuals to participate in their political system and mainly the authoritarian power of king was ceased in law-making and the kingmakers (Oyomesi) had regarded as absolute power over the rest of citizens in impeachment of the Oba or king and other governmental councils without popular consultation. While the Northern part of Nigeria could be regarded as centralized government due to the absolute power being ordained by the religious leaders most especially the Emir or king who happened to be the head of government and also powered to nominate the other cabinets without popular consultation, as we knew monarch system is a system of government rule by one either kings or queen without popular consultation. However, all these three ethnics mode of government in Nigeria were deregularised in 1976 as result of Local government reform.

In 1898, Nigeria was named from the words of Niger and Area (Nigeria) by the colonial masters, during this period Nigeria was divided into three protectorates which were popularly known as Northern, Southern protectorate and Lagos colony however, the southern and Lagos protectorate were formed together in 1906 to Southern and Lagos protectorate before Southern/Lagos and Northern protectorates amalgamated in 1914 to Protectorate of Nigeria by Sir. Lord lugurd with introduction of indirect rule. This indirect rule was introduced in order to be fully dominated political and socio-economic sectors and whereby 
the traditional rulers were used to collected tax as result of arable land, lock of personnel, etc. Nevertheless this indirect rule did not successful in the Eastern part of Nigeria as result of decentralized system of government and also led to Aba women riot of 1929. But it was successfully in the Northern and western parts due to centralized system of government. Indeed, Nigerian government started conducting general election from around 1922 to 2019. The 1922 to 1959 general election were conducted by the colonial rulers whereby few people were being given opportunity to vote most especially the females were absolutely declined to participate in politics which brought low participation or parochial political culture. Before the reformation of local government, the colonial masters have already had impact in the Nigerian democracy by giving authoritarian licenses for Nigeria in 1922 to establish political party in order to promote level of political participation. But according to the history had made us deduce that it was only one political party formed by Nigerian nationalist, Late, Herbert Maculay for participation in the 1923, 1928 and 1931 general elections before the creation of Nigerian Youth Movement. Aftermath, the some others political parties later formed base on regional councils. In the Northern part of Nigeria had established their political party which was popular known as Northern People Party (NPP), the western part of Nigeria had Action Group (AG) and the Eastern part of Nigeria had NCNC (although it was National council of Nigeria and Cameron before it's later metamorphosed to National council of Nigerian citizen in 1950s). There was development in creation of regions mostly from 1922 to 1946, to be recalled in 1922 Nigeria was provinces before it was later divided into three Regions (i.e. Northern, Western and Eastern) in 1946 by Sir, Richard (the colonial master). As result of regional reformations with aiming of adoption of federal system in the aforementioned year was later impassionate in 1954 constitution. It was this constitution granted federal system of government which both general government and sub-national government to have their jurisdictions and moreover, gave room for some Nigerian representatives to be demanded for decolonization in 1956. The representatives from Eastern and Western teamed together to have independent in 1956 which was later against by the Northern people party's leaders. Indeed, the northern people willingly to have independent in 1959, it was however argued by some scholars with reasons behind the counter motion moved by Northern leader then as result of low level of education among the Northern leaders, that if we could be given independent in 1956, it was only the Western and Eastern parts would be core political leaders. Thus, decolonization in Nigeria came to be in 1960 with a parliamentary system of government where the Late. Tawa Balewa was prime minister and the Queen of England was the president of Nigeria.

During the years of independent as it was also argued among the some political scientist that Nigeria lacked sovereignty and separation of power among the executives, judiciary and legislature. However, The Queen of England left Nigeria and the Zik of Africa became head of state and the Supreme Court was fully added over to the Nigerian judges. But before 1960-1963 Nigerian was practiced unicameral legislative before they later jettisoned to Bicameral in the early of 1960s with creation of Upper house and existed of Lower house, although before the years the House of representative had been formed during the 1951 constitution because it was part of achievements of Macpherson constitution. Over the years Nigeria amassed their independent, attempted to conduct another election in 1963-1966 but unfortunately led to military coup d'état which led by Aguirosi. Indeed, General Aguiro who took over power from civilian government as result of political crises out broken among the civilian leaders and introduced unitary system of government (i.e absolute power in central level) which was brought another coup around the middle of 1966. This was a result of civil war of 1967-1970. In 1966 to 1975, General Yakub Gowon governed Nigeria as a military ruler with creation of twelve states before it was later transformed to Late Muritalah Ramant Muhammed. This man ruled Nigerian from 1975 but he was assassinated as marking 100 days 
in office by some military rulers. As result of this assassination brought Retired General Olusegun Obansajo who happened to be predecessor to rule Nigeria from that of ending of 1975 to 1979 Nigeria. All the agendas lay by the Muritala was later implemented by him (Olusegun Obansajo) and who also brought about Local government reform of 1976 and finally added over to civilian rulers in 1979. The Nigeria conducted second republic-general election with twelve political parties registered but was only five parties gave right to have presidential candidate which was called de-facto and others were de-jure politically. Outcome of that election made late, Alhaji Sheu Sagari (first Executive president) to be declared as a winner under the Northern people party (NPP) with the highest voting of $25 \%$ with $1 / 3$ across the federation. He ruled from 1979-1983 as head of state and government. Furthermore, Sagari was also planned to have peace and credible election in 1983 in order to run for another terms in office. He also added another one political party to the existing five, which made up six political parties recognized then but kindly unfortunate that he was overthrown by the Retired General Muahammed Buhari. Buhari made much petitions with civilian government then that it was full of corruption (miss-management of public fund) and majorly, electoral crises, Kaduna crisis (between the executives and legislatures), inter and intral-parties conflict in the country which was brought as reasons to stage the government in 1983-1985. However, it was during this period that Nigeria was diversified to Mono-political economy in 1984 which referred to oil production with declination of Agricultural sector. Over the years, that administration was signed out from the government via palace-coup led by Retired General Ibrahim Badamasi Babangida in 1985. Babangida stepped into power in that year with some reformation of political system such as reformation of local government where he introduced presidential form of government to the local government in situation whereby the chairman will be the head of executive councils and the secretary, treasure etc. would be regarded as officers to local government because before it was the secretary of various local governments referred to main executive head. However, it was his administration (Babangida) introduced actual two party systems which were later resulted to abuse of power and democracy at large. Babangida conducted election in 1993 with two political parties and indeed, such election was regarded as peaceful, credible, transparent, free and fair election but was very slap to Nigerian then that the winner of the election, Late, MKO Abiola popularly known as June 12 which we are normally celebrating as a democracy day as it was amended by incumbent President Muhammed Buhari in 2019. With a planning, such power of president was transferred to interim president which was called Sonykan. Sonykan was also gained power in 1993 and lasted for six months (6) before, the late General Abarcha became the president from 1993-1998 (5 years). Kindly unfortunate, in the middle night day of 1998 declared him as late president and replaced by the Ret. Abubukar Abdulsalam because as they believed that a country can live within 24 hours without having head of state and government. Ret; General Abdulsalam amassed power in the great year of 1998 to 1999 before he was later willingly given to the civilian government in the 1999. Throughout of these years Nigeria has 36 states plus federal capital territory in Abuja and 774 local governments. In 1999, Nigeria returned to civilian government.

The general election conducted with multi-parties system whereby Ret. Olusegun Obasanjo was declared as a winner of presidential poll with $2 / 3$ of 36 states in including the FCT. He ruled from that of 1999 to 2007 with a lot of negative and positives achievements. During his time, he also added on local government reform in order to bring democracy into grass root and Modern technology like Phones and some others however, it was very sad to Nigeria as he was furniture the National assembly with money which has brought inequality among the poor and rich. Besides, he was also coup on the legislatures which was resulted to lackadaisical of separation of power because many senate presidents were impeached during his day time. Furthermore, in 2007 Nigeria conducted another election where Late, Musa 
Yaradua was declared as a winner under the Umbrella of people Democratic Party (PDP). Immediately he got power and started continuing with his seven point-Agenda which was later tried to fulfill some before he later answered the call of nature in 2010. One of his achievements was deduction of price of petroleum to sixtieth-five naira per liter which was very fantastic to all Nigerian citizens. In 2010 to 2011 remained time was concluded by his depute, Dr. Good luck Ebele Johnathan as it is stated and amended in the 1999 constitution Federal Republic of Nigeria. In the 2011, Dr. Good luck Ebele Johnathan was also furthered contesting under the People Democratic Party (PDP) with present president Muhammed Buhari under CPC party but fortunately Good lock was declared as winner by defeating his opponents. He also ruled the country from 2011 to 2015 with negative and positive achievements. He came with aiming of doing good things but as result of insecurity in the country led to failure in his administration. Finally in 2015, Nigeria conducted another election which was regard as credible election with maximum participation among the citizens. During the years the legislative and executive council were in longhead which was brought transparency in government because anything that's gone in the National assembly was very cleared to the citizens which was regard as sound separation of power between the two arms then. Therefore, Last general election was also conducted in 2019 which was talked on continuity in government of President Muhammed Buahari and also recorded as low level of participation with 34.8 percent due to initial cancellation of the 2019 polls earlier scheduled for the February 16, 2019, and eventually rescheduled for February 23, 2019. Therefore, from 1960 to 2020, Nigeria has had almost 15 presidents in both Civilian and Military government.

These are questions to ask ourselves that: Is there rule of law, separation of power, Human right, check and balance, good governance, accountabilities, equality, independent of Judiciary, Justices etc among our political leaders from 1960-2020 where we are today?

\section{Conclusion}

These state and nation are general concepts which show the relationship between sovereign state and group of ethnics. Therefore, every ethnics has is mode of eating, dressing, language, food and general tradition and culture at large in a small area or arable community. For instance Yoruba, Hausa, Igbo, Fulani, Nupe, Hindi, Gbagi etc are good examples of nations. While state refers to every countries which have government, territory, sovereignty, and population. Thus, nation-state is referred to all independent countries which are governed with both internal and external sovereignty, e.g Nigeria, Ghana, India, Brazil, USA, China, Spain, Japan, Poland, United Kingdom etc are good example of nation-state.

\section{Acknowledgement}

I'm using this great opportunist to acknowledge my amiable mentors who do give me the words of encouragement in writing academic articles and some others. Indeed, I will start showing my word of appreciation by firstly thanking almighty Allah who gives knowledge and wisdom to write this work and still pray for his blessing, guidance and long live in all my endeavors.

In addition, my wonderful father (my mentor) who has been specialized in the educational line for long period of times, in person of: Prof. Muha'd Jamiu Aliu Olokokogboro, may Almighty Allah continue to be with you and all Olokogboro's family at large (Amin). Therefore, I use Dr. Letwa (HOD's political science, IBBUL) to appreciate others lecturers in the department and other faculties for the great opportunity being given to me as student may Almighty Allah continue to be with you all (Amin). 
Cited no: 2 articles published BIoHs Journal: http://www.biarjournal.com/index.php/biohs Britain International of Humanities and Social Sciences Journal is a peer-reviewed journal published in February, June and October by BIAR Publisher. BIoHS Journal welcomes research paper in humanities: language and linguistics, history, literature, performing art, philosophy, religion, visual arts. Social sciences: economic, anthropology, sociology, psychology, geography, culture and ethics studies, gender and sexuality studies, archaeology and other related fields which is published in both online and printed versions.

ISSN: 2685-3868 (online) | 2685-1989 (print)

\section{References}

Emmanson, .J. (11 February 2019). "2019 Elections: Survey Shows Nigerians Enthuse To Vote". Leadership Newspaper. Retrieved 25 February 2019.

Ndajiya Abdulrahaman (2009), "Nigeria government in Nigeria (I\&II)" Published Lecture Note.

M.N Edita (2018), "Development of constitution in Nigeria" Unpublished IBBUL Lecture note.

Murali .M., Palanisamy .K, Rajamanikam .S., Raja N.K.K. \& Sundararaman .G. (2017) "Political Science : Higher Secondary-First Year". Government of Tamilnamdu.

Sunday .I. (2017), Principles and Practice of Local Government in Nigeria. The Rock Press \& Publishing Co. 